\title{
画像情報を利用した車両の自動追尾制御
}

\author{
藤 原 直 史*1 瀬尾達也*2 松川和 史*2 尾 西 隆*1
}

\section{Vehicle-Follower Longitudinal Control with Image Processing}

\author{
Naofumi Fujiwara*1, Tatsuya Seo*2, Kazufumi Matsukawa*2 and Takashi Onishi*1
}

\begin{abstract}
This paper deals with a longitudinal vehicle-following system of two vehicles. Follower vehicle knows relative position by processing the image of preceding vehicle. In order to control speed, optimal control method is used and the cost function is concerned with the errors on command space. The object of estimate is differential of optimal control value so as to eliminate steady state error.
\end{abstract}

Key Words: Vehicle Follower Control, Image Processing

\section{1. 緒言}

ビークル・オートメーションは，近年の産業の多分野にわた るオートメーション化において，重要な位置を占めるものであ る[1]. 特に今後その重要性を増すであろう複数車両の協調制 御のひとつとして, 追尾・同䡴走行制御が挙げられる. 車両の 高密度化による高効率化を目的として複数車両に同じ軌跡を描 かせるよう制御するもので，車両群を対象とした速度・操舵制 御に関しての各研究がなされている $[2][3]$. 応用例として は，工場内での搬送作業における能率ならびにシステム変更に 対する柔軟性の向上, 自動車操縦の安全・簡易化等が挙げられ る. 先行車と同じ経路をたどるためには車両間相互の情報通信 が必要不可欠であるが，速度制御に関していうと，双方向通信 は不要で先行車から後続車への単方向通信でよいとの報告がな されている $[4]$ ．そこで本研究では，追尾走行の基本単位とな る 2 車両の追尾走行制御に注目し, 先行車からの通信を行わ ず, 先行車の位置情報を追尾車に搭載されるカメラの画像から 得る方法を提案する.

環境認識に画像処理を用いるものとして，外界をとらえた画 像の二值化微分操作により対象パターン及び障害物を抽出し, 自律移動車を誘導する方法 [5]が報告されている．この方法で は，未知の障害物に対しても回避行動がとれ，また定型行動の 組み合わせにより走行コースの変更も可能である。 しかし処理 対象とする情報量が多く，その処理に時間・費用がかかり，ま たシステムが大型化してしまう，自動追尾制御においては，動 きのある対象を自身も動いている状態で認識する必要があり，

原稿受付 1993 年 4 月 28 日

*1金沢大学工学部

*2金沢大学大学院

*'Faculty of Tochnology, Kanazawa University

${ }^{*}$ Graduate School of Technology, Kanazawa Usiversity
より速い処理が求められる. 本研究の先行車位置の計測では注 視対象をあらかじめ指定する方法をとり [6]，功走行範囲を 明るさ一定の屋内と限定し, 設定しきい值のみにより二值化さ れた画像を解析し，処理の簡素化・高速化を図る．本研究では 自動追尾の基礎研究として, 直線走行する先行車に対する追尾 制御を行う. 速度制御において最適制御則を用い, シミュレー ションと模型実験によりこの自動追尾制御の有効性を評価す る.

\section{2. 画像情報を利用した位置計測}

\section{1 位置計測}

先行車に既知形状の認識図形を取り付け, 追尾車上に乗せら れたビデオカメラで得られる画像を処理すると，対象とする認 識図形の画像上での大きさから 2 車の相対距離を求めることが できる[7].

\section{1 .1 車間距離の検出}

対象とする認識図形を一辺 $10[\mathrm{~cm}]$ の白色正方形とし, 各距 離においてカメラで画像をとらえ，その画像の大きさ（画素数 面積）を測定する. 距離と画素数の関係を最小二乗法で近似 し, 式(2-1)を得た。これにより画像の大きさを測定すれば, 先行車までの距離が計測できる.

式(2-1)の曲線を Fig. 1 に示す.

$$
\begin{aligned}
& \text { 近似曲線 } y=\exp \left(A_{0}\right) \cdot x^{A 1} \\
& x \text { : Pixel } y \text { : Distance } \\
& A_{0}=9.5642 \quad A_{1}=-5.1917 \times 10^{-1}
\end{aligned}
$$

\section{1 .2 焦点距離 $L i$ の測定}

先行車との相対位置を測定するには使用するカメラの焦点距 離 $L i$ が必要である．焦点距離 $L i$ は Fig. 2 のような位置関係 から式(2-2)のように求められる. 


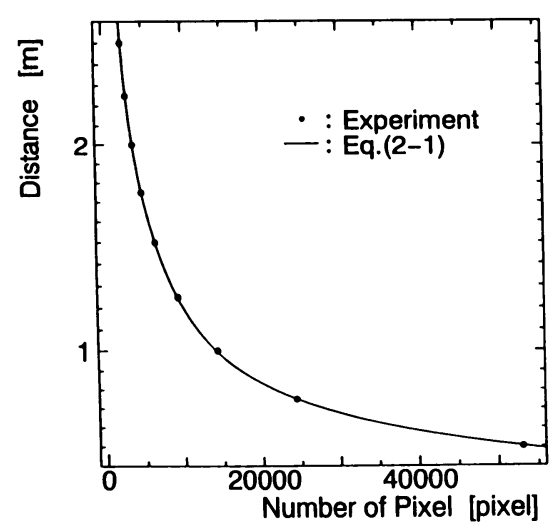

Fig. 1 Relation between Distance and the Number of Pixel

$L$ : distance to figure

$L i$ : focal distance

1 : length of figure

$1 \mathrm{i}$ : length of figure on image

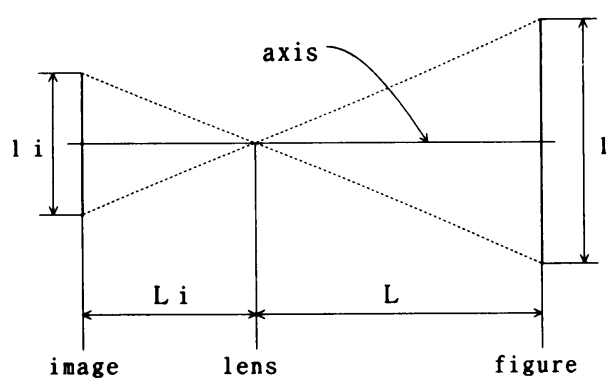

Fig. 2 measuring of focal distance $L i$

$$
L i=\frac{l i}{l} L
$$

ここでカメラの焦点距離 $L i$ を求めた結果を Fig. 3 に示す. カ メラは SONY 製の CCD-G100STを使用した．対象までの距 離を $50[\mathrm{~cm}]$ から $250[\mathrm{~cm}]$ まで $25[\mathrm{~cm}]$ 刻みで変化させ, 9 地 点で測定した．ズームは固定だがオートフォーカスを用いてい るため，対象までの距離に応じて変化する結果となった。 そこ で, より正しい焦点距離の值を得るため距離との近似曲線式(23)によって焦点距離を求める.

$$
y=\sum_{i=0}^{5} A i \cdot x^{i}
$$

$x$ : Distance $y:$ Focal Distance

$$
\begin{array}{lll}
A_{0}=1.0576 \times 10^{3} & A_{1}=2.8328 & A_{2}=-2.5274 \times 10^{-2} \\
A_{3}=1.3785 \times 10^{-4} & A_{4}=-4.1548 \times 10^{-7} & A_{5}=5.1692 \times 10^{-10}
\end{array}
$$

\section{2 位置計測法の評価}

ここで提案した計測法の有効性を実験により確かめる. 実験 結果を Table 1 に示す. カメラの最大視野角を考慮した各点で の測定結果である.

計測した結果, 距離測定における最大誤差は $3 \%$ 程度と, 許 容範囲内であることがわかった．対象までの距離の増加ととも に, 1 画素の距離測定に及ぼす影響が大きくなるため, 測定距

\begin{tabular}{|c|c|c|}
\hline Position $[\mathrm{m}]$ & experimental Value $[\mathrm{m}]$ & Errors [\%] \\
\hline$[\mathrm{deg}]$ & [deg] & {$[\%]$} \\
\hline 0.502 & 0.507 & 1.00 \\
\hline 5.39 & 5.29 & -1.86 \\
\hline 1.010 & 1.012 & 0.20 \\
\hline 8.22 & 7.78 & -5.35 \\
\hline 1.519 & 1.541 & 1.45 \\
\hline 9.15 & 8.77 & -4.15 \\
\hline 2.029 & 2.038 & $\begin{array}{c}0.44 \\
\ldots \ldots\end{array}$ \\
\hline 9.61 & 9.22 & -4.06 \\
\hline 2.538 & 2.505 & -1.30 \\
\hline 9.89 & 9.52 & -3.74 \\
\hline
\end{tabular}
離は不安定になりやすい. カメラのズームを有効利用すること で，遠距離での測定誤差を減少させることが可能であろう。ま た方位角では，誤差は最大でも $5.4 \%(0.44[\mathrm{deg}])$ 程度と，こ
Table 1 Evaluation of Measuring Methods

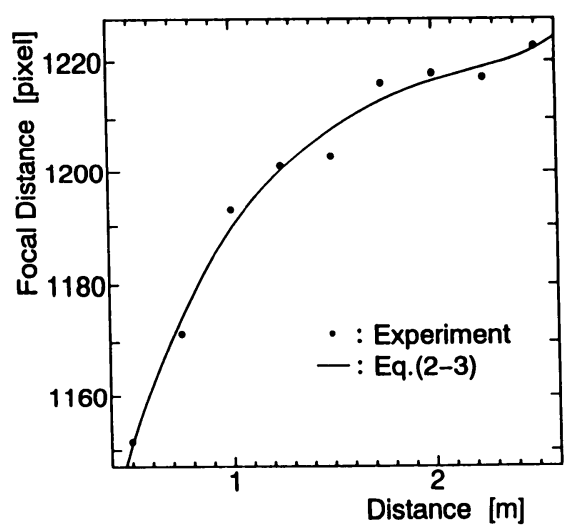

Fig. 3 Relation between Distance and Focal Distance

れも十分に許容範囲内である．誤差がすべて負の值であるの は，カメラレンズのひずみ，あるいは面像の特性の影響である と思われる. 画像の性質上, 同じ長さのものでも横方向は縦方 向に比べて画素数としては少なく検出される.そのため実際の 光軸からのずれ量よりも小さく判断し，角度としても実際より 小さく求められてしまう.より正確な值が必要な場合には，才 フセット量を加えればよい.

\section{3. 速 度 制 御}

最適制御則を用い，また，時間遅れに対する予測を加えて操 作量を算出する

\section{1 評洒対象について}

車両の動特性を次式 (3-1) とする [4].

$$
\ddot{x}=u-\alpha \dot{x}
$$

$x$ : 車両の代表点の位置, $u$ : 操作量, $\alpha:$ 正の定数

同一直線上を同一方向に進行する 2 台の車両を考える.

3.1 .1 評価対象が $u$ である場合

まず，評価関数内で評価する対象を，式(3-1)における操作 量 $u$ である場合を示す．設定車間距離を $d$ とすると，車間距 離における偏差 $e$ は

$$
e=\left(x_{1}-x_{2}\right)-d
$$


$x_{1}$ が先行車， $x_{2}$ が追尾車の代表点の位置である. 先行車が一 定速度 $v$ で走行しているとき，この $e$ に関する制御を行うこ とを考える。

$$
\begin{gathered}
\dot{e}=v-\dot{x}_{2} \\
\ddot{e}=-\alpha \dot{e}-u \\
\left(u=u_{2}-\alpha v ; \alpha, v \text { は定数 }\right)
\end{gathered}
$$

すなわち状態方程式は

$$
\frac{d}{d t}\left[\begin{array}{l}
e \\
\dot{e}
\end{array}\right]=\left[\begin{array}{cc}
0 & 1 \\
0 & -\alpha
\end{array}\right]\left[\begin{array}{l}
e \\
\dot{e}
\end{array}\right]+\left[\begin{array}{c}
0 \\
-1
\end{array}\right] u
$$

評価関数 $J$ を

$$
J=\int_{0}^{\infty}\left\{\left[\begin{array}{ll}
e & \dot{e}
\end{array}\right]\left[\begin{array}{ll}
1 & 0 \\
0 & 0
\end{array}\right]\left[\begin{array}{c}
e \\
\dot{e}
\end{array}\right]+u \cdot r \cdot u\right\} d t
$$

とする $[8] . r$ は重み係数である. 操作量 $u$ は次式(3-4)で与 えられる。

$$
u=A_{1} e(t)+B_{1} \dot{e}(t)
$$

ここで $A_{1}$ と $B_{1}$ は, リカッティの微分方程式から導かれる. このとき定常偏差は

$$
\frac{\alpha v}{A_{1}}
$$

として残ることになる.

\section{1 .2 評価対象が $\dot{u}$ である場合}

定常偏差をなくすことを考え, 評価関数内で評価する对象 を, 操作量 $u$ の微分值 $\dot{u}$ とする. 偏差 $e$ に関する前項の 2 階 微分の式より,

$$
\dddot{e}=-\alpha \ddot{e}-\dot{u}
$$

となり, 式(3-2)に対して状態方程式は

$$
\frac{d}{d t}\left[\begin{array}{c}
e \\
\dot{e} \\
\ddot{e}
\end{array}\right]=\left[\begin{array}{ccc}
0 & 1 & 0 \\
0 & 0 & 1 \\
0 & 0 & -\alpha
\end{array}\right]\left[\begin{array}{c}
e \\
\dot{e} \\
\ddot{e}
\end{array}\right]+\left[\begin{array}{r}
0 \\
0 \\
-1
\end{array}\right] \dot{u}
$$

式(3-3)に対して評価関数を

$$
J=\int_{0}^{\infty}\left\{\left[\begin{array}{lll}
e & \dot{e} & \ddot{e}
\end{array}\right]\left[\begin{array}{ccc}
1 & 0 & 0 \\
0 & 0 & 0 \\
0 & 0 & 0
\end{array}\right]\left[\begin{array}{c}
e \\
\dot{e} \\
\ddot{e}
\end{array}\right]+\dot{u} \cdot r \cdot \dot{u}\right\} d t
$$

とする.

このとき操作量 $u$ は次式(3-6)で与えられる.

$$
u=A_{2} \int e(t) d t+B_{2} e(t)+C_{2} \dot{e}(t)+u_{\mathrm{const}}
$$

ここで, $A_{2}, B_{2}, C_{2}$ はリカッティの微分方程式から導かれるも のである.この場合, 式(3-5) に対して定常偏差は 0 となる.

シミュレーション結果を Fig. 4,5 に示す $(r=1.00, \alpha=1.44, v$ $=0.30, d=2.50$ ).

\section{2 時間遅れに対する予測誤差}

操作量を算出するために使用した計測時の状態（実際の車間 距離と設定車間距離との偏差 $e$, その積分值 $\int e d t$, 微分値 $\dot{e})$ に対して, 出力時の状態は計算による時間遅れのために異 なるものとなっている．そこで二つ前の時間での状態 $E_{0}$ とひ とつ前の時間での状態 $E_{1}$ を記憶しておく．この $E_{0}$ と $E_{1}$ とを 比較し, 出力時の状態 $E_{2}=E_{1}+\left(E_{1}-E_{0}\right)$ を予測する. この $E_{2}$ に対して最適制御則を適用し, 出力值を算出する. 出力 後, $E_{1}$ であったものを $E_{0}$ とし, また実際の出力時の状態 $E_{3}$

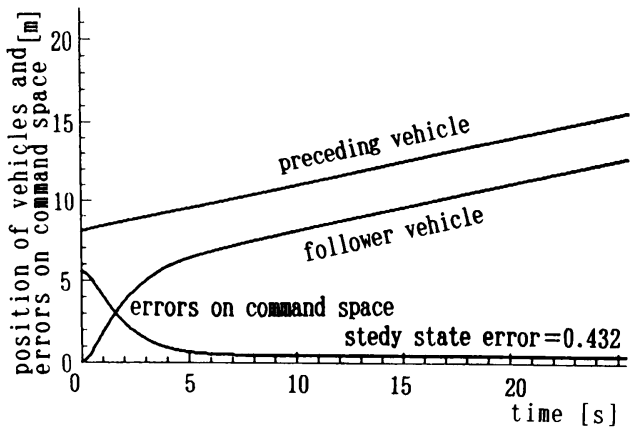

Fig. 4 Object of Estimate is $u$

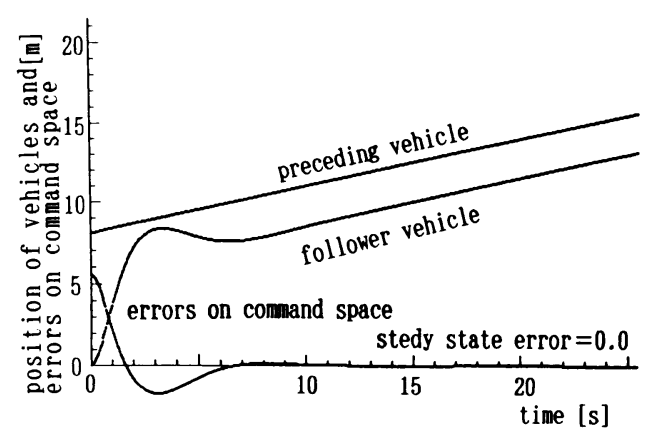

Fig. 5 Object of Estimate is $\dot{u}$

も取り込むことになるので，これを $E_{1}$ とする.

\section{3 乗用車両に対する適用 (シミュレーション)}

以上の手法を用いて乗用車両に対する適用を考える。制御に 必要な各係数はカタログの図表を用いて算出した．計測される 車間距離から操作量 $u$ が算出される.この $u$ は式(3-1)より車 両に加速度を与えるものであるため, 車重との積算により車両 に必要な駆動力 $F$ が求められる. そして車両駆動力 $F$ とトル ク $T$ との関係式(3-7) よりエンジンが発生すべき必要トルクを 求める.

$$
T=\frac{D \cdot F}{\eta_{t} \cdot n_{r}}
$$

$D$ : 駆動輪の有効径 $0.545[\mathrm{~m}], n_{r}$ : 総隇速比 14.175

$\eta_{t}$ : 動力伝達効率 0.95

またエンジン性能曲線図で機関回転数と発生トルクとの関係 が与えられているため, 式(3-8) と Fig. 6 に示す近似曲線から 必要回転数を求める. 必要卜ルクの激しい変動にもゆるやかな 回転数の変化を得るため, 3 次曲線近似としている. 実際上 は, 必要回転数が求められれば，それに比例したアクセルペダ ルストローク, 踏み込み力, 気化器開度に調整・制御すること になる。

$$
\begin{gathered}
\qquad y=\sum_{i=0}^{3} A i \cdot x^{i} \\
x: \text { Torque } \quad y: \text { Engine speed } \\
A_{0}=-1.808 \times 10^{-1} \quad A_{1}=2.872 \times 10 \\
A_{2}=-2.852 \times 10^{-1} \quad A_{3}=1.133 \times 10^{-3}
\end{gathered}
$$

さて，短時間に大きな回転数の上昇は不可能であるため，ア クセル踏み込み速度を設定する必要がある。この踏み込み速度 


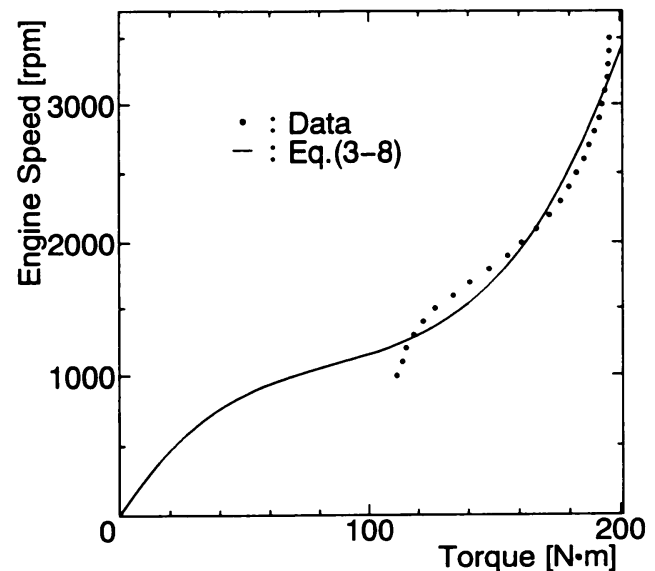

Fig. 6 Relation between torque and engine speed

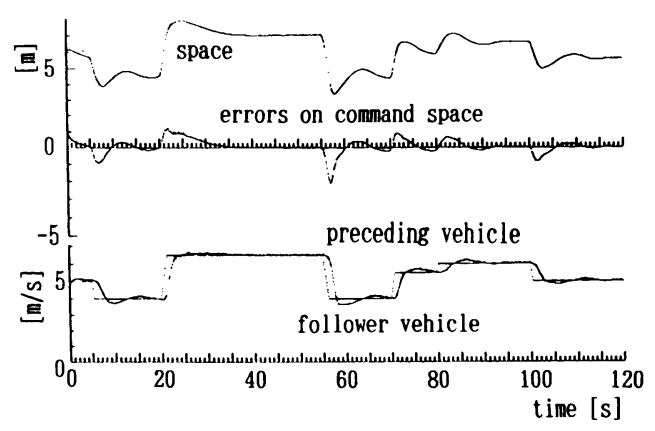

Fig. 7 Results of Simulation Experiment

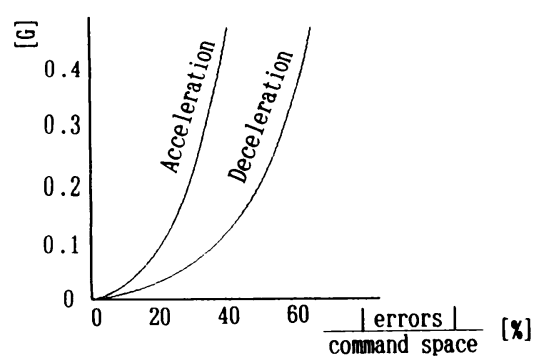

Fig. 8 Change of Acceleration and Deceleration

を小さく設定することによって走行性能曲線図の実現がなさ れ，バックトルクすなわちエンジンブレーキの影響も含まれ る.しかし小さく設定したままだと，大きく離されてしまった ときにいつまでも速度が上昇せず，追尾が不可能となるため， そのときの車間距離に応じて設定したアクセル踏み込み速度, ブレーキ操作速度に制御する．各設定量をT Table 2,3 に示す。

シミュレーション結果をFig. 7 亿示す、設定車間距離は安 全停止距離を考慮し, 速度によって変化させるものとする.

シミュレーション結果より，先行車の速度変化に十分に対応 して，追突することなく車間をとって追尾できることがわか る. また, 加速・減速の両制御において各 $G$ の与え方は段階的 にしてある.その切り換え時にショックが出て乗り心地に悪影 響を与えるのであれば，Fig. 8 のような関数を作り，それに従
Table 2 Acceleration

\begin{tabular}{c|r|c}
\hline compared with command space & {$[\mathrm{rpm} / \mathrm{s}]$} & {$[\mathrm{G}]$} \\
\hline less than $105 \%$ & 50 & 0.006 \\
\hline $105 \%$ or more & 100 & 0.011 \\
\hline $110 \%$ or more & 500 & 0.057 \\
\hline $115 \%$ or more & 800 & 0.091 \\
\hline $120 \%$ or more & 1500 & 0.170 \\
\hline
\end{tabular}

Table 3 Deceleration

\begin{tabular}{c|c}
\hline compared with command space & {$[\mathrm{G}]$} \\
\hline more than $90 \%$ & 0.01 \\
\hline $90 \%$ or less & 0.05 \\
\hline $80 \%$ or less & 0.10 \\
\hline $70 \%$ or less & 0.20 \\
\hline $60 \%$ or less & 0.40 \\
\hline
\end{tabular}

一般渋滞路における加速度範囲：0.1〜0.17[G]

減速度範囲：0.1 0.2[G]

異和感のない減速度範用：0.4[G]以下

つて $G$ を与えることでよりなめらかな乗り心地を実現でき る. 曲線の曲率を変えることによって, 加速感・減速感を変化 させることも可能であろう.

\section{4. 追 尾 実 験}

追尾実験を行い，速度制御法の有効性を確かめる.

\section{1 実験装置}

追尾車として自動車を用いたかったのだが，それがないため に市販のラジオコントロールカーを用い, これにオートフォー カスビデオカメラを搭載する. コントローラとしてはパソコン を用いたので，画像信号はケーブル，制御信号は無線を用い た。先行車に取り付けられた認識図形をとらえたカメラからの 画像は，画像取り込みボードにおいて二值化される. 二值化の 境界值であるしきい值は，周囲の明るさによって変える必要が あるが，先行車に取り付けた認識図形に蛍光灯の灯りを照らし 続けることで明るさはほほ一定に保たれ，最初に設定した值を 変える必要はなくなった，画像処理により検出された車間距離 をもとに設定車間距離との偏差を求め, 操作量を算出し, D/ $\mathrm{A}$ 変換ボードを経て送信機への出力がなされる，実験装置を

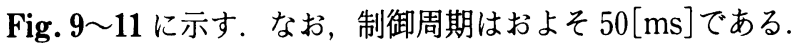

\section{2 シミュレーション}

前章での手法を適用し，シミュレーションを行う。制御に必 要な各値は基礎実験により求めた。

短時間の大幅な入力電圧の増加に対する実車の実現可能な加 速度を考慮せねばならない.モーターへの入力電圧の変動が激 しいと，車輪が空転し，駆動できなくなる，また使用する車両 はブレーキ装置がないため，急激な加速は追突の危険性を持 つ.そこで前節での手法を用い，電圧増加量を設定することに する. その場合分けを Table 4,5 に示す．通常時は制御周期 1 


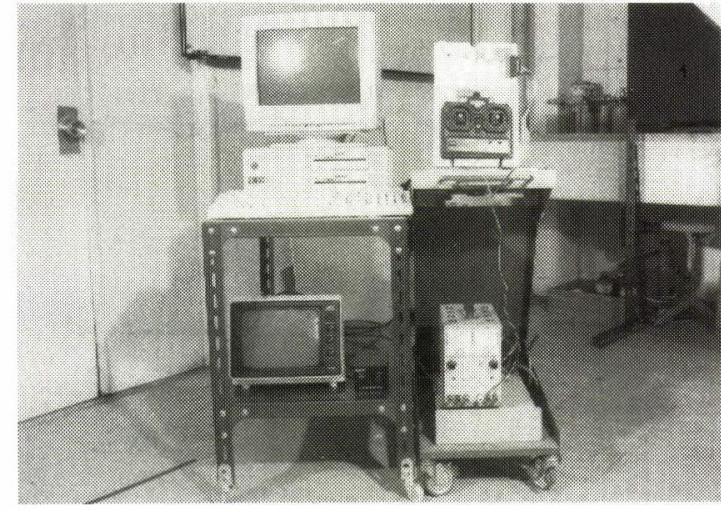

Fig. 9 Calculating and Transmitter System

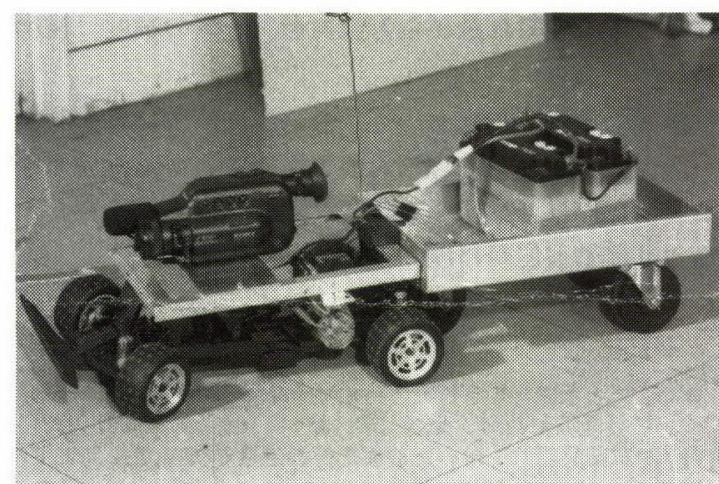

Fig. 10 Receiver (Follower Vehicle)

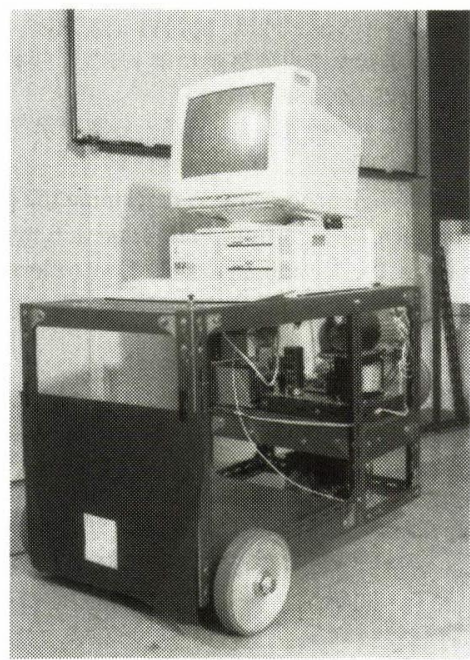

Fig. 11 Preceding Vehicle

回 (刻み幅 $0.1[\mathrm{~s}]$ ) につき 0.001 [volt] の増減とする。なお，車 間距離が設定車間距離の $50 \%$ 以下にまで近づいた場合には, 停止電圧まで下げるものとする.

初期速度 $0.50[\mathrm{~m} / \mathrm{s}]$, 設定車間距離 $1.10[\mathrm{~m}]$, 先行車の加 減速度 $0.098\left[\mathrm{~m} / \mathrm{s}^{2}\right](\fallingdotseq 0.01[\mathrm{G}])$, 重み係数 1.00 とした場合 のシミュレーション結果を Fig. 12 に示す.

結果より,この設定值程度の加速度であれば先行車の加速に
Table 4 Acceleration

\begin{tabular}{c|c}
\hline compared with command space & per one loop $[$ volt $]$ \\
\hline $105 \%$ or more & 0.003 \\
\hline $110 \%$ or more & 0.005 \\
\hline $115 \%$ or more & 0.007 \\
\hline $120 \%$ or more & 0.010 \\
\hline
\end{tabular}

Table 5 Deceleration

\begin{tabular}{c|c}
\hline compared with command space & per one loop [volt] \\
\hline $95 \%$ or less & -0.01 \\
\hline $90 \%$ or less & -0.03 \\
\hline $85 \%$ or less & -0.05 \\
\hline $80 \%$ or less & -0.07 \\
\hline $50 \%$ or less & stop volt \\
\hline
\end{tabular}

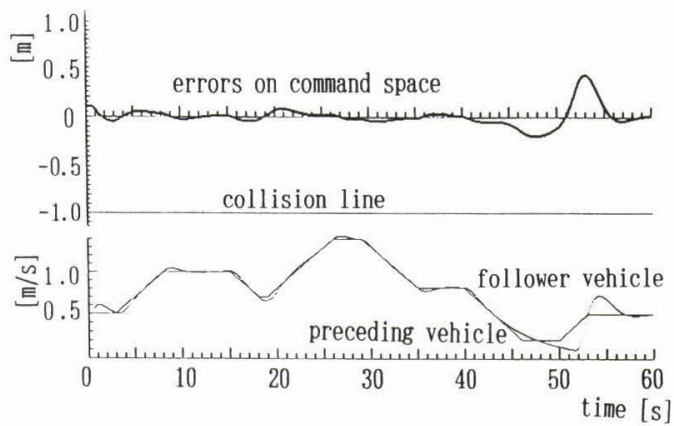

Fig. 12 Results of Simuration Experiments

は余裕をもって追従できることがわかる. しかし減速時, 特に 時刻 45〜 55[s]付近において, 車間距離の偏差が増大してい る. その原因は, 車両の減速装置の不備による操作量算出時の 偏差積分項の増大である. 偏差の累積の影響を明らかにしたも のが Fig. 13 と Fig. 14 である。ともに初期車間距離は $0.10[\mathrm{~m}]$, 設定車間距離は $1.0[\mathrm{~m}]$ である. 追尾開始時には両 車両ともに停止状態である. Fig. 13 では先行車は時刻 $1.0[\mathrm{~s}]$ においてスタートし， $0.50[\mathrm{~m} / \mathrm{s}]$ まで加速する. 先行車の加速 度は, $0.098\left[\mathrm{~m} / \mathrm{s}^{2}\right]$ である. Fig. 14 では先行車のスタート時刻 を $5.0[\mathrm{~s}]$ としている. 他の值はすべて同一である. Fig. 13 と 比較すると, 偏差量の累積が多くなる結果，その収束に時間が かかることがわかる.

以上のことより，使用した車両では加速追従時には問題はな いが，減速時には速度との兼ね合いで減速時に留意する必要が ある。また長時間, 設定車間距離との偏差を持ち続けるような 状態は, その後の不安定要因となるため, 避けるべきである.

\section{3 実験結果}

先行車は設定車間距離の $40 \%$ 増しの位置から, 加速度 $0.20\left[\mathrm{~m} / \mathrm{s}^{2}\right]$ で $0.28[\mathrm{~m}]$ まで加速し, 定速走行する. 重み係数 の值は 45.0 である。設定車間距離は $0.80[\mathrm{~m}]$, 走行距離はお よそ $12[\mathrm{~m}]$ である. 実験結果を Fig. 15 に示す. 


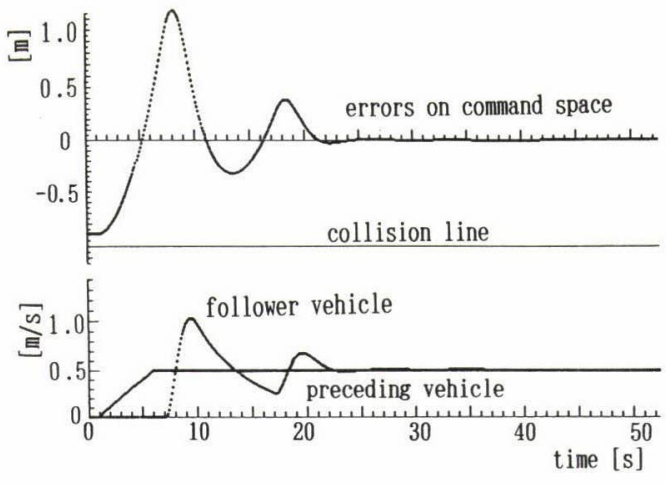

Fig. 13 Preceding Vehicle starts at $1.0[\mathrm{~s}]$

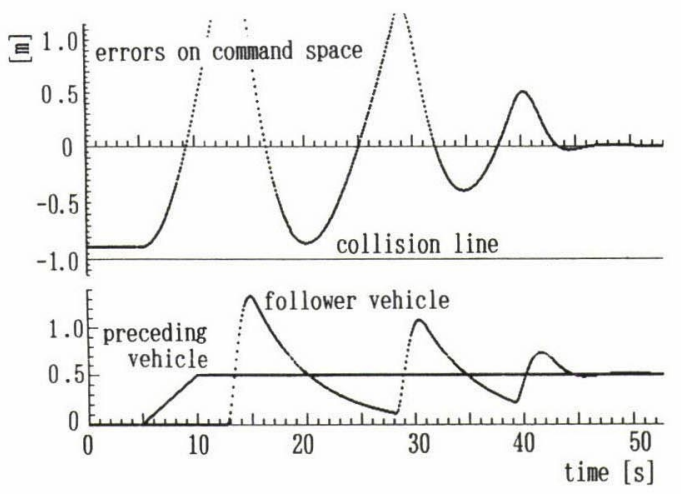

Fig. 14 Preceding Vehicle starts at 5.0[s]

車間距離は設定車間距離に収束することがわかる．相対速度 は, 計測車間距離の変化量から求めているためにばらつきが見 られるが, その変化の仕方を見ると設定車間距離との偏差に応 じている.

\section{5. 結 論}

画像情報のみを用いた 2 車間の相対位置の検出方法を提案 し，以下に示すことをシミュレーションと実験によって確かめ た.

1）あらかじめ定めた認識図形を用いることにより，その距

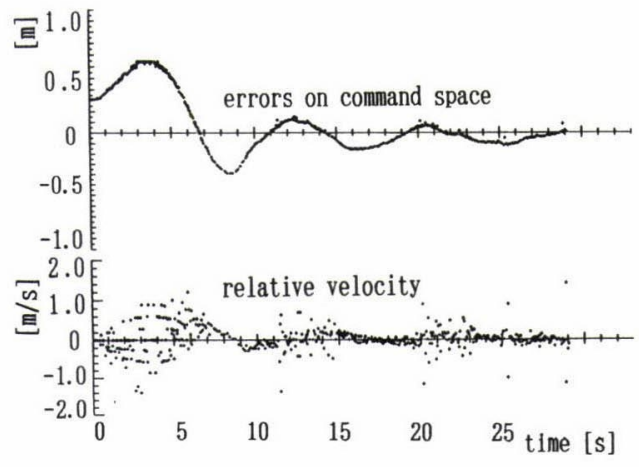

Fig. 15 Experimental Results

離と画素数の関係の近似曲線によって距離を, またカメラ光軸 からの対象中心のずれ量から方位角を，一定の精度で検出する ことが可能である.

2）車両の追尾制御において，その速度制御に最適制御則を 用い，操作量の微分値を評価対象とすることで定常偏差をなく し, さらに操作量増減速度を設定と変化量の予測を取り入れる ことにより自動追尾が可能である.

\section{参 考 文 献}

[1] 津村,“ピークル・オートメーション（各種移動体の自動化・自律化に ついての最近の動向”, 金沢工業会誌 no. 108, pp. 28-33, 1992.

[2] 津川,“車両間通信を用いた追従走行の速度制御”, 第 4 回アドパンテ イ・シンポジウム講演論文集, pp. 35-38, 1991.

[3] 津村,“車両群の自動追従走行システム”, 第 3 回アドバンティ・シンポ ジウム講演論文集, pp. 19-22, 1990.

[4] 津川,“車両間通信による車両の追従走行制御”, 第 10 回ピークル・オ ートメーション・シンポジウム, pp. 111-114, 1987.

[5] 森,“構内道路を走行する自律移動ロボット”, 日本ロボット学会誌 vol. 5 no. 5, pp. 29-42, 1987.

[6]石黒,“移動ロボットの視覚システム”, 日本ロボット学会誌 vol. 10 no. 2, pp. 21-26, 1992.

[ 7 ] I. Fukui, “TV image processing to determine the position of robot vehicle," Pattern Recognition, vol. 14, no. 1-6, pp. 101-109, 1981.

[8] M. Athans, "On the Design of P-I-D Controllers Using Optimal Linear Regulator Theory," Automatica, vol. 7, pp. 643-647, 1971.

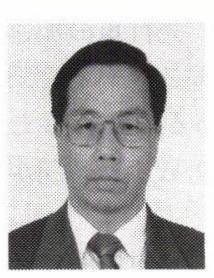

藤原直史（Naofumi Fujiwara）

1942 年 11 月 22 日生. 1965 年大阪府立大学工学部 航空工学科卒. 同年大阪府立大学工学部助手. 1989 年金沢大学教授 (機械システム工学科) 現在に 至る. 移動体の位置計測, 誘導に関する研究に従 事. 日本機械学会, 計測自動制御学会, システム 制御情報学会, ビークルオートメーション技術研

究会会員.

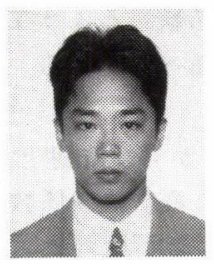

松川和史（Kazufumi Matsukawa）

1970 年 3 月 17 日生. 1992 年金沢大学工学部機械 システム工学科卒. 1994 年同大学院修士課程修 了. 同年 (株) ダイフク勤務.

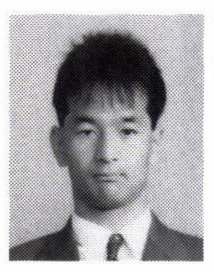

瀬尾達也（Tatsuya Seo）

1969 年 2 月 26 日生. 1991 年金沢大学工学部機械 システム工学科卒. 1993 年同大学院修士課程修 了. 同年ヤマ八 (株) 勤務.

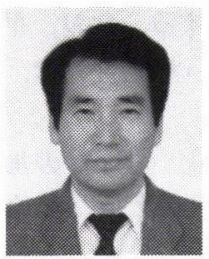

1945 年 10 月 20 日生. 1964 年金沢大学工学部勤 務, 技術部技術専門職員. 